\title{
Plasma catecholamines during exercise-induced bronchoconstriction in bronchial asthma
}

\author{
JAN ZIELIŃSKI, EWA CHODOSOWSKA, ADAM RADOMYSKI, ZUZANNA ARASZKIEWICZ, \\ AND STANISLAW KOZLOWSKI
}

From the Department of Medicine, Institute of Tuberculosis, and Department of Applied Physiology, Experimental and Clinical Medical Research Centre, Polish Academy of Science, Warsaw, Poland

\begin{abstract}
Plasma levels of adrenaline and noradrenaline during and after submaximal exercise in patients with bronchial asthma were investigated. Three groups were studied comprising 10 patients with exercise-induced bronchoconstriction (EIB), 10 asthmatic patients without EIB and four normal control subjects. Plasma catecholamines were measured at rest, at the end of exercise, and five and 15 minutes after exercise. Changes in airway resistance were assessed by measuring peak expiratory flow rate. Significant differences in catecholamine levels between reacting and non-reacting patients were found. In 10 patients developing EIB adrenaline and noradrenaline levels had risen significantly by the end of exercise and remained elevated up to the fifth minute of recovery. The rise in catecholamine levels in non-reacting asthmatics was insignificant. In control subjects noradrenaline had increased significantly by the end of exercise.
\end{abstract}

Despite many years of investigation some aspects of exercise-induced bronchoconstriction (EIB) remain unclear. Its mechanism is not yet known nor are the reasons for its appearance after completion of exercise rather than during it. It is well known that plasma catecholamine levels increase during physical exercise. ${ }^{1}$ A rise in noradrenaline level depends on the work performed in relation to the maximal oxygen uptake. ${ }^{2}{ }^{3}$ Adrenaline level rises only at a very high workload. ${ }^{45}$

Adrenaline is one of the most potent endogenous bronchodilators. Noradrenaline induces a constriction of bronchial smooth muscle. Respective levels and reciprocal relations between adrenaline and noradrenaline during and after physical exercise in patients with bronchial asthma may influence the time of onset and the course of EIB.

The aim of this study was to investigate the changes in catecholamine levels during and after exercise in asthmatic patients with and without EIB.

\section{Methods}

Twenty patients with atopic asthma were studied. The diagnosis was based on history, positive skin

Address for reprint requests: Dr J Zielinski, Department of Medicine, Institute of Tuberculosis, Plocka 26, 01-138 Warszawa, Poland. tests, and eosinophilia in the blood or sputum. The patients were divided into two groups according to their response to exercise. The first group comprised 10 patients developing EIB. The second contained asthmatics without EIB. Four healthy members of the medical staff made up the control group. In order to avoid a large range of physical performance between subjects, an age of 39 years was taken as an upper limit for admission to the study.

It was noted in general that patients with EIB had more severe asthma than non-reactors. Their mean basal PEFR was lower, they were using more drugs, two of them were on continuous steroids therapy and they were physically less fit. Non-reactors were on intermittent beta-adrenergic stimulating drugs only. The majority of this group were students regularly performing sporting activity.

Exercise tests were done in a sitting position on a bicycle ergometer. A steady-state submaximal exercise of 10 minutes was performed by each subject, the workload being individually adjusted during preparatory tests to achieve a steady heart rate ranging between $80-90 \%$ of predicted maximal heart rate. ${ }^{6}$ Peak expiratory flow rate was measured in the sitting position at rest and at one, five, and 15 minutes after the completion of exercise using a Wright peak flow meter. Patients in whom the PEFR fell 
by more than $20 \%$ of the resting value were placed in the EIB group.

The investigations were performed in the morning at a room temperature of around $20^{\circ} \mathrm{C}$. All medications were withdrawn eight hours before testing. Patients were familiar with the procedure as preparatory exercising was performed in the same surroundings and supervised by the same people. Each subject rested for half an hour in a supine position before the initial resting venous blood sample from a previously sited cannula was taken. Consecutive blood samples were taken at the tenth minute of exercise and at five and 15 minutes after the end of exercise.

The blood was put into heparinised polyethylene tubes containing sodium pyrosulphide, immediately centrifuged and the serum frozen. Adrenaline and noradrenaline levels were determined by the fluorimetric method of Anton and Sayre, ${ }^{7}$ the laboratory normal values for noradrenaline being $0.94 \pm 1.04 \mu \mathrm{g} / 1$ and for adrenaline $0.35 \pm 0.09 \mu \mathrm{g} / \mathrm{l}$. The error of the method is $\pm 0.02 \mu \mathrm{g} / \mathrm{l}$, recovery for adrenaline being $72 \%$ and that of noradrenaline $77 \cdot 2 \%$.

Blood pressure measurements and ECG, lead $\mathrm{V}_{5}$, were recorded every two minutes during cxercise. Statistical analysis of the data made use of paired $t$ testing, correlation coefficients, and multifactorial regressions.

\section{Results}

Mean age and heart rate at rest and on exercise (also expressed as a percentage of predicted maximal heart rate) are shown in table 1 . Exercise tolerance was lowest in patients with EIB and highest in control subjects. The scatter of exercise heart rate in each group was small averaging $88-89 \%$ of the maximal predicted heart rate. $^{6}$

Table 2 shows change in PEFR and catecholamine levels at rest, on exercise, and after exercise in patients developing bronchospasm. Peak

Table 1 Age and heart rate at rest and on exertise in three studied groups. Mean, standard deviations, and range are shown

\begin{tabular}{lllll}
\hline & \multirow{2}{*}{$\begin{array}{l}\text { Age } \\
(y r)\end{array}$} & \multicolumn{3}{l}{ Heart rate beats/min } \\
\cline { 2 - 4 } & Rest & Exercise \% of predicted maximal \\
\hline Group 1 & $26 \cdot 7 \pm 6 \cdot 5$ & $74 \pm 10$ & $174 \pm 1088 \pm 4$ \\
& $17-37$ & $60-92$ & $156-18582-94$ \\
Group 2 & $24 \cdot 6 \pm 6 \cdot 7$ & $81 \pm 9$ & $177 \pm 489 \pm 4$ \\
& $17-38$ & $60-96$ & $174-18684-98$ \\
Control & $31 \cdot 5 \pm 6 \cdot 4$ & $73 \pm 7$ & $172 \pm 889 \pm 4$ \\
Subjects & $26-38$ & $64-82$ & $163-17884-94$ \\
\hline
\end{tabular}

expiratory flow rate was lowest five minutes after completing exercise. The mean fall in PEFR at $\frac{\bar{m}}{\bar{m}}$ that time was $39 \%(p<0.001)$. There was a significant increase in catecholamine levels on exercise. Noradrenaline rose from $0.88 \pm 0.21 \mu \mathrm{g} / 1$ to के $1.32 \pm 0.40 \mu \mathrm{g} / 1 \quad(\mathrm{p}<0.001)$. Five minutes after $\vec{\circ}$ exercise these levels decreased but remained signi- $\vec{\overrightarrow{ }}$ ficantly higher than at rest $(p<0 \cdot 05)$. Fifteen $\vec{\omega}^{\circ}$ minutes after exercise they returned to the initial values.

Table 3 shows the above-mentioned parameters in asthmatic patients without EIB. There was a $\vec{\longrightarrow}$ small statistically insignificant increase in PEFR after exercise in this group. There was also a $\omega$ small statistically insignificant rise in catechol- 윽 amine levels at the end of exercise. On recovery $\rightarrow$ these levels had returned to resting values.

Table 4 shows changes in PEFR and catecholamine levels induced by exercise in the control subjects. Noradrenaline level rose from $1 \cdot 15 \pm 0 \cdot 23$ $\mu \mathrm{g} / 1$ at rest to $1.43 \pm 0.27 \mu \mathrm{g} / 1$ on exercise $(\mathrm{p}<0.01)$ and fell rapidly to resting levels on recovery.

There was no correlation between catecholamine levels at rest, on exercise, or on recovery except between resting values in the group with EIB $(r=0.84)$ and in the tenth minute of exercise

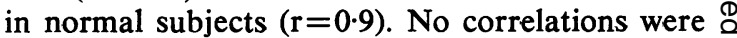
observed in any group between PEFR and $\overrightarrow{\vec{O}}$ adrenaline or noradrenaline separately or together.

\section{Discussion}

The study has shown that there were substantial differences in catecholamine levels in asthmatic subjects submitted to physical exercise depending on whether EIB was present or not. Thus an increase in catecholamine levels on exercise and early in the post-exercise phase was found in 우 patients reacting with EIB but no significant change was observed in patients not developing EIB.

Our findings on catecholamine levels in patients or with EIB are consistent with previous reports. ${ }^{8-10} \sim$ Although these authors also found increased $\underset{\omega}{N}$ catecholamine levels during and immediately after exercise they doubt that this rise plays $a_{0}$ role in the development of EIB. Their opinion is $\stackrel{\mathbb{D}}{\stackrel{D}{0}}$ based on the observation that the changes in $\stackrel{?}{+}$ catecholamine levels in asthmatic patients do not $\square$ differ from those seen in normal controls, ${ }^{8-10}$ and $\bar{O}$ that they found no correlation between catechol- $\mathbb{\mathbb { D }}$ amine levels and increased airway resistance. ${ }^{910} \mathbb{\mathrm { D }}$

We have not found a paper comparing catecholamine levels in asthmatic patients with and 
Table 2 Plasma catecholamine and peak expiratory flow (PEFR) values in 10 asthmatic patients developing exercise-induced bronchoconstriction

\begin{tabular}{|c|c|c|c|c|c|c|c|c|c|c|c|c|c|c|}
\hline \multirow[t]{3}{*}{ Patient } & \multirow[t]{3}{*}{$\operatorname{Sex}$} & \multicolumn{5}{|c|}{ PEFR $l / \min$} & \multicolumn{8}{|c|}{ Catecholamine $\mu \mathrm{g} / 1$} \\
\hline & & \multirow[t]{2}{*}{ Initial } & \multirow[t]{2}{*}{$\begin{array}{l}\% \text { of } \\
\text { predicted }\end{array}$} & \multicolumn{3}{|c|}{ After exercise } & \multicolumn{2}{|c|}{ Initial } & \multicolumn{2}{|c|}{ End of exercise } & \multicolumn{2}{|c|}{$\begin{array}{l}5 \text { min after } \\
\text { exercise }\end{array}$} & \multicolumn{2}{|c|}{$\begin{array}{l}15 \text { min after } \\
\text { exercise }\end{array}$} \\
\hline & & & & $1 \min$ & $5 \min$ & $15 \mathrm{~min}$ & $A$ & $N A$ & $A$ & $N A$ & $A$ & $N A$ & $A$ & $N A$ \\
\hline $\begin{array}{r}1 \\
2 \\
3 \\
4 \\
5 \\
6 \\
7 \\
8 \\
9 \\
10\end{array}$ & $\begin{array}{l}\mathbf{M} \\
\mathbf{M} \\
\mathbf{F} \\
\mathbf{F} \\
\mathbf{F} \\
\mathbf{M} \\
\mathbf{M} \\
\mathbf{F} \\
\mathbf{M} \\
\mathbf{F}\end{array}$ & $\begin{array}{l}270 \\
285 \\
375 \\
420 \\
370 \\
370 \\
540 \\
390 \\
365 \\
390\end{array}$ & $\begin{array}{l}45 \\
46 \\
91 \\
99 \\
84 \\
62 \\
84 \\
89 \\
73 \\
93\end{array}$ & $\begin{array}{l}340 \\
150 \\
360 \\
335 \\
285 \\
355 \\
460 \\
300 \\
430 \\
340\end{array}$ & $\begin{array}{l}235 \\
125 \\
260 \\
235 \\
220 \\
185 \\
375 \\
150 \\
330 \\
265\end{array}$ & $\begin{array}{l}210 \\
125 \\
280 \\
210 \\
215 \\
170 \\
425 \\
195 \\
380 \\
285\end{array}$ & $\begin{array}{l}0.42 \\
0.35 \\
0.47 \\
0.25 \\
0.28 \\
0.32 \\
0.29 \\
0.29 \\
0.35 \\
0.37\end{array}$ & $\begin{array}{l}0.93 \\
0.82 \\
1.38 \\
0.53 \\
0.85 \\
0.83 \\
0.73 \\
0.87 \\
0.98 \\
0.85\end{array}$ & $\begin{array}{l}0.56 \\
0.60 \\
0.47 \\
0.44 \\
0.34 \\
0.46 \\
0.46 \\
0.75 \\
0.52 \\
0.60\end{array}$ & $\begin{array}{l}1 \cdot 31 \\
1 \cdot 12 \\
2 \cdot 22 \\
1 \cdot 15 \\
1 \cdot 01 \\
1 \cdot 25 \\
0 \cdot 78 \\
1 \cdot 68 \\
1 \cdot 51 \\
1 \cdot 14\end{array}$ & $\begin{array}{l}0.56 \\
0.61 \\
0.39 \\
0.37 \\
0.26 \\
0.41 \\
0.45 \\
0.30 \\
0.44 \\
0.57\end{array}$ & $\begin{array}{l}1.04 \\
1 \cdot 16 \\
0.87 \\
0.92 \\
0.87 \\
1 \cdot 18 \\
1 \cdot 21 \\
1.01 \\
1 \cdot 24 \\
1 \cdot 34\end{array}$ & $\begin{array}{l}0.35 \\
0.24 \\
0.33 \\
0.31 \\
0.20 \\
0.29 \\
0.35 \\
0.38 \\
0.32 \\
0.21\end{array}$ & $\begin{array}{l}0.93 \\
0.81 \\
0.59 \\
0.66 \\
0.55 \\
1.11 \\
1.13 \\
0.92 \\
1.17 \\
0.81\end{array}$ \\
\hline \multicolumn{2}{|c|}{$\begin{array}{l}\text { Mean } \\
\text { Standard deviation } \\
\text { p }\end{array}$} & $\begin{array}{l}387 \cdot 5 \\
78\end{array}$ & $\begin{array}{r}76 \cdot 60 \\
4 \cdot 32\end{array}$ & $\begin{array}{c}335 \cdot 5 \\
84\end{array}$ & $\begin{array}{l}238 \cdot 0 \\
76 \\
<0.001\end{array}$ & $\begin{array}{l}249.5 \\
94 \\
<0.001\end{array}$ & $\begin{array}{l}0.34 \\
0.07\end{array}$ & $\begin{array}{l}0 \cdot 88 \\
0 \cdot 21\end{array}$ & $\begin{aligned} & 0.52 \\
& 0.11 \\
&<0.001\end{aligned}$ & $\begin{array}{l}1.32 \\
0.40 \\
<0.001\end{array}$ & $\begin{array}{r}0.44 \\
0.12 \\
<0.05\end{array}$ & $\begin{array}{r}1.08 \\
0.17 \\
<0.05\end{array}$ & $\begin{array}{l}0.30 \\
0.06 \\
\text { NS }\end{array}$ & $\begin{array}{l}0.87 \\
0.22 \\
\text { NS }\end{array}$ \\
\hline
\end{tabular}

p values concern difference between initial and respective value of studied variable.

NS $=$ not significant $(p>0.05) . A=$ adrenaline, $\mathbf{N A}=$ noradrenaline.

Table 3 Plasma catecholamine and peak expiratory flow (PEFR) values in 10 asthmatic patients not developing exercise-induced bronchoconstriction

\begin{tabular}{|c|c|c|c|c|c|c|c|c|c|c|c|c|c|c|}
\hline \multirow[t]{3}{*}{ Patient } & \multirow[t]{3}{*}{ Sex } & \multicolumn{5}{|c|}{ PEFR $l / m i n$} & \multicolumn{8}{|c|}{ Catecholamine $\mu \mathrm{g} / 1$} \\
\hline & & \multirow[t]{2}{*}{ Initial } & \multirow[t]{2}{*}{$\begin{array}{l}\% \text { of } \\
\text { predicted }\end{array}$} & \multicolumn{3}{|c|}{ After exercise } & \multicolumn{2}{|c|}{ Initial } & \multicolumn{2}{|c|}{ End of exercise } & \multicolumn{2}{|c|}{$\begin{array}{l}5 \text { min after } \\
\text { exercise }\end{array}$} & \multicolumn{2}{|c|}{$\begin{array}{l}15 \text { min after } \\
\text { exercise }\end{array}$} \\
\hline & & & & $I \min$ & $5 \min$ & 15 min & $\boldsymbol{A}$ & $N A$ & $A$ & $N A$ & $A$ & $N A$ & $A$ & $N A$ \\
\hline $\begin{array}{r}1 \\
2 \\
3 \\
4 \\
5 \\
6 \\
7 \\
8 \\
9 \\
10\end{array}$ & $\begin{array}{l}\mathbf{M} \\
\mathbf{M} \\
\mathbf{M} \\
\mathbf{F} \\
\mathbf{M} \\
\mathbf{M} \\
\mathbf{F} \\
\mathbf{M} \\
\mathbf{M} \\
\mathbf{M}\end{array}$ & $\begin{array}{l}415 \\
385 \\
580 \\
420 \\
530 \\
570 \\
430 \\
460 \\
470 \\
425\end{array}$ & $\begin{array}{r}72 \\
63 \\
91 \\
105 \\
89 \\
93 \\
100 \\
72 \\
71 \\
65\end{array}$ & $\begin{array}{l}460 \\
420 \\
660 \\
430 \\
580 \\
585 \\
460 \\
410 \\
525 \\
480\end{array}$ & $\begin{array}{l}360 \\
365 \\
590 \\
400 \\
535 \\
550 \\
440 \\
425 \\
485 \\
470\end{array}$ & $\begin{array}{l}355 \\
400 \\
590 \\
410 \\
510 \\
570 \\
430 \\
440 \\
480 \\
465\end{array}$ & $\begin{array}{l}0.81 \\
0.40 \\
0.32 \\
0 \cdot 28 \\
0.31 \\
0 \cdot 29 \\
0.28 \\
0.41 \\
0.32 \\
0.32\end{array}$ & $\begin{array}{l}1.56 \\
1.27 \\
0.83 \\
1.04 \\
0.83 \\
0.66 \\
0.89 \\
0.87 \\
0.81 \\
1.19\end{array}$ & $\begin{array}{l}0.52 \\
0.44 \\
0.36 \\
0.35 \\
0.36 \\
0.41 \\
0.52 \\
0.30 \\
0.51 \\
0.54\end{array}$ & $\begin{array}{l}1 \cdot 25 \\
1.04 \\
1.07 \\
1 \cdot 14 \\
0.99 \\
1 \cdot 29 \\
1.40 \\
0.87 \\
1.00 \\
1.71\end{array}$ & $\begin{array}{l}0.56 \\
0.26 \\
0.26 \\
0.29 \\
0.23 \\
0.42 \\
0.51 \\
0.79 \\
0.49 \\
0.65\end{array}$ & $\begin{array}{l}1.09 \\
1.27 \\
0.87 \\
1.03 \\
0.72 \\
1.15 \\
1.00 \\
1.00 \\
1.20 \\
1.30\end{array}$ & $\begin{array}{l}0.49 \\
0.20 \\
0.24 \\
0.24 \\
0.29 \\
0.24 \\
0.28 \\
0.28 \\
0.29 \\
0.52\end{array}$ & $\begin{array}{l}0.98 \\
0.74 \\
0.87 \\
1.00 \\
1.04 \\
0.81 \\
0.71 \\
0.67 \\
0.90 \\
1.14\end{array}$ \\
\hline \multicolumn{2}{|c|}{$\begin{array}{l}\text { Mean } \\
\text { Standard deviation } \\
\mathbf{p}\end{array}$} & $\begin{array}{l}468 \cdot 5 \\
\quad 68\end{array}$ & $\begin{array}{l}82 \cdot 1 \\
15\end{array}$ & $\begin{array}{l}501 \cdot 0 \\
84 \\
\text { NS }\end{array}$ & $\begin{array}{c}462 \cdot 0 \\
79 \\
\text { NS }\end{array}$ & $\begin{array}{l}465 \cdot 0 \\
75 \\
\text { NS }\end{array}$ & $\begin{array}{l}0.38 \\
0 \cdot 16\end{array}$ & $\begin{array}{l}1 \cdot 00 \\
0 \cdot 27\end{array}$ & $\begin{array}{l}0.43 \\
0.09 \\
\text { N3 }\end{array}$ & $\begin{array}{l}1 \cdot 18 \\
0 \cdot 25 \\
\text { NS }\end{array}$ & $\begin{array}{l}0.45 \\
0.19 \\
\text { Ni }\end{array}$ & $\begin{array}{l}1 \cdot 06 \\
0 \cdot 18 \\
\text { NS }\end{array}$ & $\begin{array}{l}0 \cdot 31 \\
0 \cdot 11 \\
\text { Ni }\end{array}$ & $\begin{array}{l}0.89 \\
0.15 \\
\text { NS }\end{array}$ \\
\hline
\end{tabular}

Notes and abbreviations as in table 2 .

Table 4 Plasma catecholamine and peak expiratory flow (PEFR) values in four healthy men subjected to submaximal physical exercise

\begin{tabular}{|c|c|c|c|c|c|c|c|c|c|c|c|c|c|}
\hline \multirow[t]{3}{*}{ Number } & \multicolumn{5}{|c|}{ PEFR $l / \min$} & \multicolumn{8}{|c|}{ Catecholamine $\mu \mathrm{g} / 1$} \\
\hline & \multirow[t]{2}{*}{ Initial } & \multirow[t]{2}{*}{$\begin{array}{l}\% \text { of } \\
\text { predicted }\end{array}$} & \multicolumn{3}{|c|}{ After exercise } & \multicolumn{2}{|l|}{ Initial } & \multicolumn{2}{|c|}{ End of exercise } & \multicolumn{2}{|c|}{$\begin{array}{l}5 \text { min after } \\
\text { exercise }\end{array}$} & \multicolumn{2}{|c|}{$\begin{array}{l}15 \text { min after } \\
\text { exercise }\end{array}$} \\
\hline & & & $I \min$ & 5 min & $15 \mathrm{~min}$ & $A$ & $N A$ & $\boldsymbol{A}$ & $N A$ & $A$ & $N A$ & $\boldsymbol{A}$ & $N A$ \\
\hline $\begin{array}{l}1 \\
2 \\
3 \\
4\end{array}$ & $\begin{array}{l}600 \\
540 \\
680 \\
560\end{array}$ & $\begin{array}{r}103 \\
87 \\
113 \\
89\end{array}$ & $\begin{array}{l}585 \\
540 \\
670 \\
585\end{array}$ & $\begin{array}{l}520 \\
535 \\
620 \\
550\end{array}$ & $\begin{array}{l}570 \\
540 \\
620 \\
555\end{array}$ & $\begin{array}{l}0.44 \\
0.36 \\
0.23 \\
0.41\end{array}$ & $\begin{array}{l}1.01 \\
1.08 \\
1.01 \\
1.48\end{array}$ & $\begin{array}{l}0.40 \\
0.40 \\
0.33 \\
0.51\end{array}$ & $\begin{array}{l}1 \cdot 50 \\
1 \cdot 27 \\
1 \cdot 18 \\
1 \cdot 78\end{array}$ & $\begin{array}{l}0.33 \\
0.37 \\
0.26 \\
0.36\end{array}$ & $\begin{array}{l}1.08 \\
1.04 \\
1.00 \\
1.19\end{array}$ & $\begin{array}{l}0.22 \\
0.33 \\
0.23 \\
0.24\end{array}$ & $\begin{array}{l}0.69 \\
0.69 \\
0.82 \\
0.99\end{array}$ \\
\hline $\begin{array}{l}\text { Mean } \\
\text { Standard } \\
\text { deviation } \\
\text { p }\end{array}$ & $\begin{array}{l}595 \cdot 0 \\
62\end{array}$ & $12 \cdot 3$ & $\begin{array}{c}595 \cdot 0 \\
54\end{array}$ & $\begin{array}{r}556 \cdot 3 \\
44 \cdot 2\end{array}$ & $\begin{array}{r}571 \cdot 3 \\
34 \cdot 7\end{array}$ & $\begin{array}{l}0.36 \\
0.09\end{array}$ & $\begin{array}{l}1 \cdot 15 \\
0 \cdot 23\end{array}$ & $\begin{array}{l}0.41 \\
0.07 \\
\text { N5 }\end{array}$ & $\begin{array}{r}1.43 \\
0.27 \\
<0.01\end{array}$ & $\begin{array}{l}0.33 \\
0.05 \\
\text { NS }\end{array}$ & $\begin{array}{l}1.08 \\
0.08 \\
\text { NS }\end{array}$ & $\begin{array}{l}0.26 \\
0.05 \\
\text { NS }\end{array}$ & $\begin{array}{l}0.80 \\
0.14 \\
\text { N3 }\end{array}$ \\
\hline
\end{tabular}

Notes and abbreviations as in table 2. 
without EIB. The difference in catecholamine levels between these two groups suggests that an increased noradrenaline level on exercise and in the early post-exercise period may play a role in the mechanism of EIB. Perhaps this occurs as a result of sensitisation of receptors in smooth muscle. Another possibility would be a summation effect of noradrenaline and the actual mediator of bronchoconstriction.

In a previous study ${ }^{11}$ we have found indirect evidence that histamine is a probable mediator of EIB. Our hypothesis was subsequently supported by Anderson et al who found an increase in blood histamine level during EIB. ${ }^{12}$ In a recent study Radomyski et $a^{13}$ also found that whole blood histamine in eight asthmatic patients developing EIB increased from a resting level of $64 \pm 24.4 \mu \mathrm{g} / 1$ to $75 \pm 21 \mu \mathrm{g} / 1$ at the end of submaximal exercise $(\mathrm{p}<0.05)$.

There is some evidence that alpha receptor blockade prevents histamine-induced bronchoconstriction, ${ }^{1415}$ or protects asthmatic patients against EIB. ${ }^{16} 17$ Here one might assume that noradrenaline released during exercise stimulates alpha receptors in the bronchial smooth muscles sensitising them to the histamine.

The significant increase in adrenaline levels in patients with EIB not seen in normal controls may have resulted from mental stress. These patients were submitted to at least one preparatory test after which they developed severe bronchospasm which was not reversed for 15 minutes. Anticipation of the same unpleasant sensation may have caused the increase in adrenaline level.

It is difficult to explain why in non-reacting asthmatic patients the noradrenaline level on exercise did not increase significantly as was seen in reactors and control subjects, particularly as the relative heart rates were similar in all three groups. Non-reacting subjects did not receive any treatment that could interfere with catecholamine release or with the rate of elimination of noradrenaline from the circulation. McDermott et $a l^{18}$ have found that catecholamine release during exercise was higher in older men (mean age 46.8 years) than in younger ones (mean age 25.3 years). Although our non-reacting subjects were younger than reactors and control subjects, the intergroup age differences were probably too small to be responsible for the differences in noradrenaline release.

Apart from being younger the non-reacting subjects also regularly performed physical exercise, whereas the reactors and control subjects led a sedentary life. Davies ${ }^{19}$ has shown that the prediction of maximal oxygen uptake from heart rate can be a source of important underestimation. It might be assumed that in spite of the $\vec{\nabla}$ same relative heart rate as the other groups, non- $\Omega$ reacting patients were working at lower relative क oxygen consumption. Were this the case it may $\overrightarrow{0}$ have accounted for the lower noradrenaline increase on exercise.

We thank Mrs Wanda Radziszewska for carrying out the catecholamine measurements and Dr w Elżbieta Zołocińska-Lao for help in testing the patients. Our special thanks are due to our col- $\infty$ leagues who kindly agreed to take part in the $\underset{\omega}{\mathscr{\omega}}$ study as control subjects.

\section{References}

1 Banister EW, Griffiths J. Blood levels of adrenergic amines during exercise. $J$ Appl 응 Physiol 1972; 33:674-6.

2 Hüggendal J, Hartley LH, Saltin B. Arterial $\vec{\bullet}$

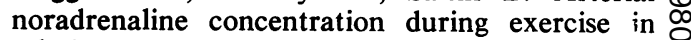
relation to relative work levels. Scand J Clin Lab Invest 1970; 26:337-42.

3 Hartley LH, Mason JW, Hogan RP. Multiple hormonal responses to graded exercise in relation $\bar{\partial}$ to physical training. J Appl Physiol 1972; 33: 602-6.

4 Kozlowski S, Brzezinska Z, Nazar K, Kowalski ำ W. Activation of adrenergic system during exercise in men in relation to work load and 3 physical working capacity. Bull Acad Pol Sci (Biol) 1972; 20:897-901.

5 Kotchen TA, Hartley LH, Rice TW. Renin, norepinephrine, and epinephrine responses to $\mathrm{O}$

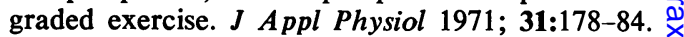

6 Astrand PO, Rodahl K. Manuel de physiologie ơ de l'exercise musculaire. Paris: Masson et $\mathrm{Cie}, \underline{3}$. 1973.

7 Anton TH, Sayre DF. A study of factors affecting the aluminium oxide-trihydroxyindole procedure for the analysis of catecholamines. $J$ Pharm Exp Ther 1962; 138:360-75.

8 Anderson SD, Pojer R, Smith ID, Temple D. Exercise-related changes in plasma levels of $N$ 15-keto-13, 14-dihydro-prostaglandin $F_{2} \alpha$ and $G$ noradrenaline in asthmatic and normal subjects. $N$ Scand J Respir Dis 1976; 57:41-8.

9 Beil M, Brecht HM, Rasche B. Plasma catecholamines in exercise induced bronchoconstriction. Klin Wochenschr 1977; 55:577-81. 을

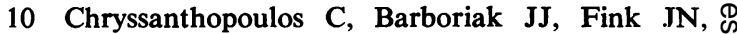
Stekiel WJ, Maksud MG. Adrenergic responses of asthmatic and normal subjects to submaximal 0 and maximal work levels. J Allergy Clin Immunol 1978; 61:17-22.

11 Zielinski J, Chodosowska E. Exercise-induced bronchoconstriction in patients with bronchial asthma. Its prevention with an antihistaminic 
agent. Respiration 1977; 34:31-5.

12 Anderson SD, Ferris L, Temple DM, Allen D, Lindsay DL. Arterial blood histamine and cyclic AMP levels in exercise-induced asthma. Am Rev Respir Dis 1978; 117: suppl no. 4/2, 55.

13 Radomyski A, Chodosowska E, Chrostowski K, Zielinski J, Araszkiewicz Z. Histaminemia w przebiegu powysilkowego skurczu oskrzeli u chorych z astma oskrzelowa. Pol Arch Med Wewn 1980; 63:81-5.

14 Kerr JW, Govindaraj M, Patel KR. Effect of alpha receptor blocking drugs and disodium chromoglycate on histamine hyper-sensitivity in bronchial asthma. $\mathrm{Br} \mathrm{Med} J$ 1970; 2:139-41.

15 Gaddie J, Legge JS, Petrie G, Palmer KNV. The effect of alpha adrenergic receptor blocking drug on histamine sensitivity in bronchial asthma. Br J Dis Chest 1972; 66:141-6.

16 Bianco S, Griffin JP, Kamburoff PL, Prime FJ. Prevention of exercise-induced asthma by indoramin. Br Med J 1974; 4:18-20.

17 Patel KR, Kerr JW, MacDonald EB, MacKenzie AM. The effect of thymoxamine and cromolyn sodium on post-exercise bronchoconstriction in asthma. J Allergy Clin Immunol 1976; 57:285-92.

18 McDermott DJ, Stekiel WJ, Barboriak JJ, Kloth LC, Smith JJ. Effect of age on hemodynamic and metabolic response to static exercise. J Appl Physiol 1974; 37:923-6.

19 Davies CTM. Limitations to the prediction of maximum oxygen intake from cardiac frequency measurements. J Appl Physiol 1969; 24:700-6. 